\author{
Multidisciplinary \\ SCIENTIFIC JOURNAL OF \\ MARITIME RESEARCH
}

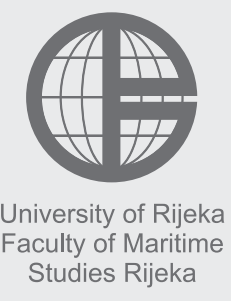

Multidisciplinarni

znanstveni časopis

POMORSTVO

\title{
The impact of employee education and knowledge on the logistics processes in Slovenian companies
}

\author{
Sebastjan Škerlič \\ University of Ljubljana, Faculty of Maritime Studies and Transport, Pot pomorščakov 4, 6320 Portorož, Slovenia, e-mail: sebastjan.skerlic@fpp.uni-lj.si
}

\begin{abstract}
A statistical analysis has been conducted on a sample of 30 Slovenian companies, the main purpose of which was to determine the impact of the level of education of logistics employees and the logistics knowledge of employees from other departments on the logistics processes of companies. It has been determined that the acquired level of education has a significant impact on the level of logistics costs in larger companies. The results of the survey have also proved that the quality of logistical processes is higher in companies where employees from other departments possess a wide range of logistical knowledge. The results obtained represent an important finding for the logistic profession in Slovenia and for the wider region, since logistics is an area that continues to be dominated by employees with a lower level education.
\end{abstract}

\section{ARTICLE INFO}

Preliminary communication

Received 23 August 2017

Accepted 28 November 2017

\section{Key words:}

Logistics processes

Logistics costs

Logistics education

Logistics knowledge

Slovenia

\section{Introduction}

The development of information technology (advanced programmes and decisions-making tools), work instruments (RFID, Barcode, etc.), means of transport (efficient and economical vehicles) and the traffic network (new road, rail, air, sea connections and distribution centres) enables a wide selection of innovative logistics solutions [16]. However, the choice is often related to finding the optimal cost-benefit ratio of logistics services. Different studies [2, $10,14,15]$, highlighted that, as the quality of logistics services for the customer increases, end customer satisfaction increases as well, but it also results in higher logistics costs. Research $[2,6,20]$ also points out that logistics costs are interdependent, since the reduction of the cost of one logistics activity leads to an increase in the cost of other logistics activities, which ultimately results in higher overall costs.

Knowledge is therefore crucial for controlling logistic processes. Companies that are unable to efficiently use their employees' knowledge of logistics will find it more difficult to coordinate their own supply chain in the future, as logistics will play a key role in lowering costs and improving the level of customer service. By improving the educational structure of the employees involved in logis- tics, we also strengthen the knowledge of employees who deal with complex logistical issues concerning the controlling of the logistics costs of a company. Investing in education also strengthens the logistics intellectual capital of the company. The logistics knowledge of employees from other departments can also have a positive influence on managing logistics processes, as a lack of awareness of the interdependence of logist ics costs in sales and purchasing activities can disrupt a company's operations as a modern supply chain element.

All the factors described above affect the logistics of a company in different ways and can help improve the controlling of logistics processes. In support of these arguments, a survey has been conducted on a sample of 30 Slovenian companies, with the objective of determining the degree to which each of these factors affects the level of logistics costs and the quality of the logistics processes of a company. A comparison has also been made between companies with less than 250 employees and companies with more than 250 employees. The survey is not only relevant for Slovenian companies, but also for the logistics industry in the wider region, as it provides clear guidelines for future improvements in the field of managing logistics processes in companies. 


\section{Literature review}

Argote and Ingram [1] define knowledge transfer as the process through which one unit is affected by the experience of another, since knowledge does not exist independently of a relationship with a particular event, idea, or other person. Wheatley [21] emphasizes that knowledge is created in relationships, inside thinking, as a result of the interaction between employees in a company. However, Nam-Hong Yim and others [11] point out that employees in the company functional departments have a limited knowledge in certain situations. Their partial knowledge, which comes from different sources, has to be transformed and combined into an integrated model with the goal of transferring knowledge among the logistic system's creators.

That is why various authors in the field of controlling logistics processes have devoted their work to developing various methods and models. The most widely emphasized method is Activity Based Costing (ABC), on which several logistical studies are based and which were later developed by their authors [3, 5, 7-9, 12, 13, 17-19] to manage costs in different segments of the logistics business of companies.

On the other hand, the development of logistics cost models has reached a point that makes it impossible to be user friendly for potential users in companies. Logistics cost models transfer into science important mathematical solutions in terms of solving complex and complicated logistics problems. However, the knowledge transmitted by the development of different heuristic approaches and algorithmically structured models is accessible to a narrower circle of experts. Models with this structure do not facilitate the participation of employees, who, through the transfer of knowledge and experience, are important co-creators of a company's logical intellectual capital. Therefore, not every process is capable of establishing useful knowledge and thus organizing the basic principles of creating knowledge that will be useful to the company in the long run [4].

Stock and Lambert [15] emphasize the fact that when logistics experts focus solely on reducing costs to justify their existence, the management is more prone to view logistics as an area for cost reduction. If logistics experts wish to be appreciated for their achievements, they must also direct their efforts towards enhancing the educational structure of the logistics staff.

\section{Data and methods}

Out of the 40 companies that have been asked to take part in the survey, 10 companies opted not to participate. The final sample has been comprised of 30 companies. For the purpose of the survey, an online questionnaire has been set up and forwarded to the management of each company, together with an invitation (in writing and by telephone) to take part in the survey.
The share of logistic costs in the company revenue has been an ordinal variable measured on a four point scale ( $1=<5 \% ; 2=5-9 \% ; 3=10-20 \% ; 4=>20 \%$ ). The quality of business processes has been measured by five fivepoint Likert-type items for which factor analysis showed one underlying factor. The average score on five items has been computed and used as a measure of business process quality in the analysis. Education of employees responsible for logistics has been measured by the share of employees in the logistic department with higher rather than high school education. Logistic knowledge of employees from other departments has been measured by one fivepoint Likert type item. Association between education of employees responsible for logistics and logistic knowledge of employees from other departments and logistic costs has been examined by Spearman correlation coefficient. Association between the stated variables and quality of business processes has been measured by Pearson correlation coefficient.

Analysis has been carried out on a subset of companies by their size ( $\leq 250$ and $>250$ employees) and on all companies included in the sample. The level of statistical significance has been set to $\alpha=0.05$ (one-tailed) when factors influencing lower logistic costs have been examined as direction of associations has been presupposed. The statistical analysis has been performed in IBM SPSS 22.0 .

\section{Results analysis}

The survey sample has included 2 companies with 11 to 50 employees (6.7\%), 13 companies with 51 to 250 employees (43.3\%) and 15 companies with more than 250 employees (50\%). The logistics departments of the companies employ $12.4 \%$ of employees with primary school education, $60.6 \%$ employees with vocational or secondary level education and 27\% with at least higher-level education or post-secondary education (Figure 1).

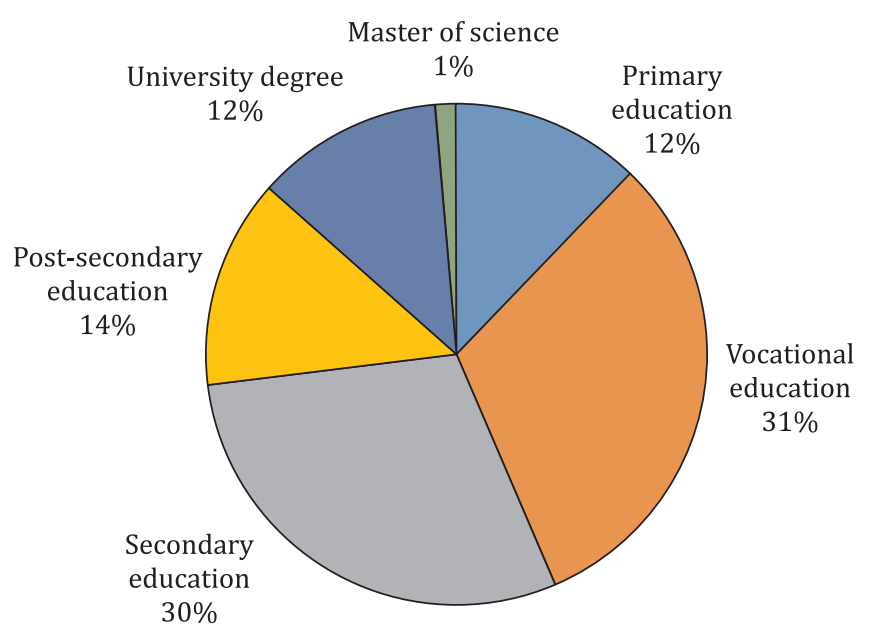

Figure 1 Number of Employees in Logistics by Level of Education 


\begin{tabular}{|l|c|c|}
\hline $\begin{array}{c}\text { Transport costs in the company } \\
\text { logistics costs structure }\end{array}$ & f & f $\%$ \\
\hline$<15 \%$ & 10 & 34,48 \\
\hline od $15 \%$ do $29 \%$ & 7 & 24,14 \\
\hline od $30 \%$ do $60 \%$ & 4 & 13,79 \\
\hline $60 \%$ & 3 & 10,34 \\
\hline Not observed separately & 5 & 17,24 \\
\hline
\end{tabular}

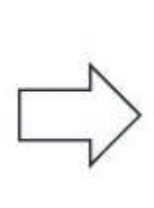

\begin{tabular}{|l|c|c|}
\hline $\begin{array}{c}\text { Logistics costs in the } \\
\text { company revenue }\end{array}$ & f & f $\%$ \\
\hline$<5 \%$ & 19 & 63,33 \\
\hline od $5 \%$ do $9 \%$ & 5 & 16,67 \\
\hline od $10 \%$ do $20 \%$ & 3 & 10,00 \\
\hline $20 \%$ & 1 & 3,33 \\
\hline Not observed separately & 2 & 6,67 \\
\hline
\end{tabular}

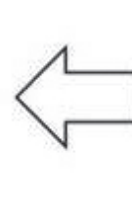

\begin{tabular}{|l|c|c|}
\hline $\begin{array}{c}\text { Warehousing costs in the company } \\
\text { logistics costs structure }\end{array}$ & f & f \% \\
\hline$<15 \%$ & 18 & 62,07 \\
\hline od $15 \%$ do $29 \%$ & 3 & 10,34 \\
\hline od $30 \%$ do $60 \%$ & 2 & 6,90 \\
\hline$<60 \%$ & 0 & 0,00 \\
\hline Not observed separately & 6 & 20,69 \\
\hline
\end{tabular}

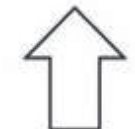

\begin{tabular}{|l|c|c|}
\hline $\begin{array}{c}\text { Other logistics costs in the company } \\
\text { logistics costs structure }\end{array}$ & f & f \% \\
\hline$<5 \%$ & 7 & 24,14 \\
\hline od $5 \%$ do $9 \%$ & 6 & 20,69 \\
\hline od $10 \%$ do $20 \%$ & 10 & 34,48 \\
\hline $20 \%$ & 2 & 6,90 \\
\hline Not observed separately & 4 & 13,79 \\
\hline
\end{tabular}

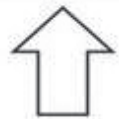

\begin{tabular}{|l|c|c|}
\hline $\begin{array}{c}\text { Cost associated with the logistics costs - } \\
\text { Other logistics costs }\end{array}$ & f & f \% \\
\hline Inventory costs & 19 & 65,52 \\
\hline Operating staff costs & 17 & 58,62 \\
\hline Information system costs & 13 & 44,83 \\
\hline The cost of lost sales - non delivery of goods & 11 & 37,93 \\
\hline Cost of production interruption & 8 & 27,59 \\
\hline Other & 4 & 13,79 \\
\hline
\end{tabular}

Figure 2 Distribution of Logistics Costs in Surveyed Companies

Figure 2 shows the distribution of logistics costs. In more than half of the companies (63.3\%), the share of logistics costs in sales revenue is $<5 \%$. In ten companies, the share of transport costs in the overall structure of logistics costs is $<15 \%$, while in 18 companies the same applies to warehousing costs. Data on the share of other logistics costs in the overall structure of logistics costs is more scattered. In 7 of the companies this share is $<5 \%$, in 6 of the companies the share ranges between 5\% and $9 \%$, in 10 of them the share is $10 \%$ to $20 \%$, and in 2 of the companies the share is $>20 \%$. Four of the companies do not calculate logistics costs separately from other costs. The costs that are most often associated with other logistics costs in the company are the costs of inventory (65\%), operating staff costs (58.6\%), information system costs (44.8\%), the cost of lost sales due to failure to supply goods to the customer $(37.9 \%)$, and the cost of production interruption $(27.6 \%)$.

Table 1 provides an assessment of business processes. The surveyed companies regularly measure the level of the customer satisfaction with the timeliness of delivery. The companies are strongly oriented towards the development of innovation and provide high quality logistic processes, but there is also a strong cooperation between departments. They also measure the customer satisfaction with their services.

Table 2 provides an assessment of the customer demand for business process improvements. The demands are very substantial, since the median is $\mathrm{Me}=4$ for all the statements.

Table 1 Evaluation of Business Processes

\begin{tabular}{|c|c|c|c|c|c|c|}
\hline & Min & Max & AM & Me & SD & $\mathbf{N}$ \\
\hline $\begin{array}{l}\text { We regularly measure the customer satisfaction with the timeliness of our } \\
\text { deliveries }\end{array}$ & 3 & 5 & 4.6 & 5.0 & 0.6 & 29 \\
\hline Our company is strongly oriented towards the development of innovations & 3 & 5 & 4.2 & 4.0 & 0.7 & 29 \\
\hline Our company provides a guarantee of high quality for logistic processes & 3 & 5 & 3.9 & 4.0 & 0.7 & 29 \\
\hline There is strong cooperation between departments in the company & 2 & 5 & 3.9 & 4.0 & 0.7 & 29 \\
\hline
\end{tabular}

$*$ Min = minimum value; $\mathrm{Max}=$ maximum value; $\mathrm{AS}=$ arithmetic mean; $\mathrm{Me}=$ median; $\mathrm{SD}=$ standard deviation; $\mathrm{N}=$ number of respondents 
Table 2 Assessment of the Customer Demand for Business Process Improvements

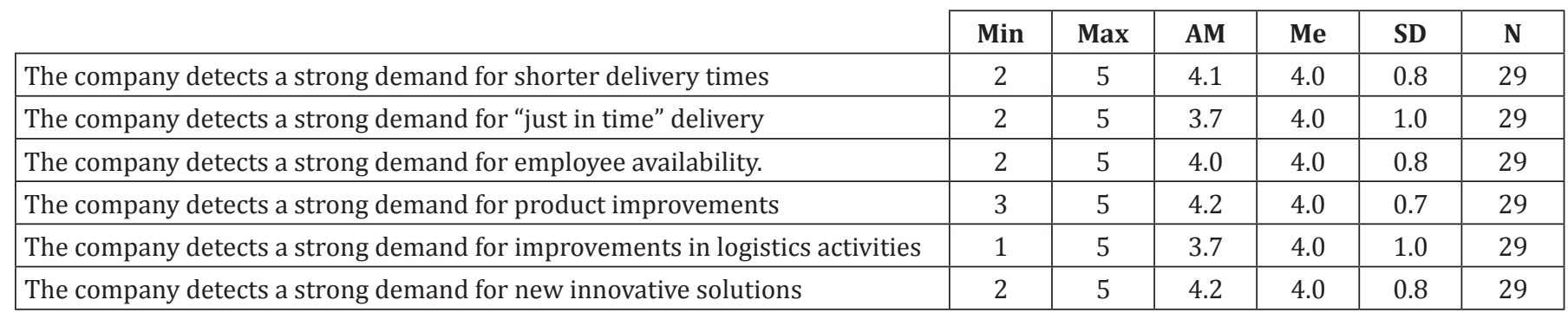

${ }^{*}$ Min = minimum value; Max = maximum value; $\mathrm{AS}=$ arithmetic mean; Me = median; $\mathrm{SD}=$ standard deviation; $\mathrm{N}=$ number of respondents

In Table 3 Spearman correlation coefficients between education of employees responsible for logistics and logistic knowledge of employees from other departments on one hand and logistic costs on the other one with accompanying p-value are shown. No statistically significant correlation between each of the examined variables and logistic costs has been found. The analysis on the sub- groups of companies according to their size, however, has showed statistically significant negative association between the education of employees responsible for logistics in larger companies and logistic costs $(r=-0.54 ; p=0.02)$. The higher the share of employees responsible for logistics with more than high school education is, the lower the logistic costs in larger companies are.

Table 3 Spearman Correlation Coefficients between Education of Employees Responsible for Logistics and Logistic Knowledge of Employees from other Departments and Logistic Costs

\begin{tabular}{|c|c|c|c|c|c|c|}
\hline & \multicolumn{6}{|c|}{$\begin{array}{l}\text { Share of Logistics Costs in the Company Income according to the } \\
\text { Company Size }\end{array}$} \\
\hline & $\mathbf{r}$ & $\mathbf{p}$ & $\mathbf{r}$ & $\mathbf{P}$ & $\mathbf{r}$ & $\mathbf{p}$ \\
\hline & \multicolumn{2}{|c|}{$\leq 250$} & \multicolumn{2}{|c|}{$>250$} & \multicolumn{2}{|c|}{ All } \\
\hline Education of employees in the logistic department ${ }^{+}$ & 0.23 & 0,210 & -0.54 & 0.024 & -0.08 & 0.352 \\
\hline Logistic knowledge of employees from other departments & 0.30 & 0.147 & -0.02 & 0.471 & 0.16 & 0,213 \\
\hline
\end{tabular}

+ Share of employees in the logistics department with more than high-school education

Overall, business process quality is statistically significantly positively correlated with the logistics knowledge of employees from other departments (Table 4). The higher the logistic knowledge of employees from other departments is, the higher is the quality of the business process. Taking into account the size of the companies, the association is marginally statistically significant within larger companies, while in smaller companies, a statistically significantly positive correlation between the logistics knowledge of employees from other departments and business process quality exists. The education of employees in the logistics department is not statistically significantly correlated with the business process quality, regardless of the company's size.

Table 4 Pearson Correlation Coefficients between the Education of Employees Responsible for Logistics and the Logistic Knowledge of Employees from other Departments and Business Process Quality

\begin{tabular}{|c|c|c|c|c|c|c|}
\hline & \multicolumn{6}{|c|}{ Business Process Quality } \\
\hline & $\mathbf{r}$ & $\mathbf{p}$ & $\mathbf{r}$ & $\mathbf{P}$ & $\mathbf{r}$ & $\mathbf{p}$ \\
\hline & \multicolumn{2}{|c|}{$\leq 250$} & \multicolumn{2}{|c|}{$>250$} & \multicolumn{2}{|c|}{ All } \\
\hline Education of employees in the logistics department ${ }^{+}$ & 0.15 & 0.584 & -0.28 & 0.335 & -0.04 & 0.842 \\
\hline Logistics knowledge of employees from other departments & 0.68 & 0.005 & 0.49 & 0.073 & 0.64 & $<0.001$ \\
\hline
\end{tabular}

+ Share of employees in the logistics department with more than high-school education

\section{Discussion and conclusions}

Logistics is undoubtedly an industry that keeps pace with the technological development of society. More and more, businesses are becoming aware of its positive effects, which result in a reduction in total costs and a better quality of supply. For a company, having a modern logistics system can be a tool for achieving cost-effectiveness and a basis for managing the supply chain.

The results of the survey have indicated that highly educated logistics department staff plays an important role in managing logistics costs. This is true for larger 
businesses that also have lower logistical costs. This is an important finding for the academic logistics profession in Slovenia and the wider region, as it proves that the level of education acquired has a significant impact on the management of logistics costs in larger companies. These companies are also the largest employers and generators of local and national economic development. This is precisely why it is worrying that $73 \%$ of logistics employees in Slovenian companies have a level of education that is below the level of the post-secondary education, which suggests some obvious directions for future improvements in this area.

The results of the survey have also proved that the quality of logistics processes is higher in companies where employees from other departments possess a wide range of logistics knowledge. Individual business functions (e.g. sales, purchasing, production and development) have a major impact on how a company's logistics system is set up, because they are in a direct contact with the customers as early as in the product development phase. Since every purchasing, sales or production process is linked to different logistical activities, it is therefore essential for employees from other departments to possess a certain level of knowledge of logistics. Businesses should definitely invest in the logistics training of employees from other departments, since they are active participants in and co-creators of the company's supply chain.

The survey and the analysis of its results represent an important contribution to the study of how different organizational measures can improve a company's logistics and how these factors are then implemented in its business process. Another area where this survey and its results represent an important contribution is the development of business strategies for the rationalization of logistics costs and the improvement of logistics processes in companies.

Since the survey has been limited to Slovenian companies, it would be sensible to conduct a similar survey in countries that have seen a growth in investment in logistics in recent years, such as Croatia, Slovakia or the Czech Republic, and compare the results obtained.

\section{References}

[1] Argote, L. and Ingram, P.: "Knowledge transfer: A basis for competitive advantage in firms," Organizational Behavior and Human Decision Processes 82 (1), pp. 150-169, 2000.

[2] Ballou, R. H.: Business logistics management: planning, organizing, and controlling the supply chain, 4th, international ed., Prentice-Hall International; Upper Saddle River, 1999.

[3] Baykasoğlu, A. and Kaplanoğlu, V.: "Application of Activity-based Costing to a Land Transportation Company: A Case Study," International Journal of Production Economics 116(2), pp. 308-324, 2008.

[4] Blome, C., Schoenherr, T. and Eckstein, D.: "The Impact of Knowledge Transfer and Complexity on Supply Chain Flex- ibility: A Knowledge-based View," International Journal of Production Economics 147 part B, pp. 307-316, 2014.

[5] Bokor, Z.: "Integrating Logistics Cost Calculation into Production Costing," Acta Polytechnica Hungarica 9(3), pp. 163-181, 2012.

[6] Christopher, M.: Logistics and Supply Chain Management: Creating Value-Adding Networks. Financial Times. Prentice Hall : Pearson, 2005.

[7] Everaert, P., Bruggeman, W., Sarens, G., Anderson, S. R.; Levant, Y. "Cost Modeling in Logistics using Time-Driven ABC: Experiences from a Wholesaler," International Journal of Physical Distribution \& Logistics Management 38(3), pp. 172-191, 2008.

[8] Fang, Y. in Ng, S. T.: "Applying Activity-based Costing Approach for Construction Logistics Cost Analysis," Construction Innovation 11(3), pp. 259-281, 2001.

[9] Goldsby, Th.J. in Closs, D.J.: "Using Activity-based Costing to Re-engineer the Reverse Logistics Channel," International Journal of Physical Distribution \& Logistics Management 30(6), pp. 500-514, 2000.

[10] Lambert, D. M.; Burduroglu, R.: "Measuring and Selling the Value of Logistics," International Journal of Logistics Management 11(1), pp. 1-18, 2000.

[11] Nam-Hong, Y., Soung-Hie, K., Hee-Woong, K. and Kee-Young K.: "Knowledge based decision making on higher level strategic concerns: system dynamics approach," Expert Systems with Applications 27, pp. 143-158, 2004.

[12] Pohlen, T. L. and LaLonde, B. J.: "Implementing Activitybased Costing (ABC) in logistics," Journal of Business Logistics 15(2), pp. 1-23, 1994.

[13] Schulze, M.; Seuring, S. and Ewering, C.: "Applying Activitybased Costing in a Supply Chain Environment," International Journal of Production Economics 135(2), pp. 716-725, 2012.

[14] Shang Kuo-Chung: "The Effects of Logistics Measurement Capability on Performance," Asia Pacific Management Review 9(4), pp. 671-687, 2004.

[15] Stock, J. R., Lambert, D. M.: Strategic Logistics Management. 4th ed. McGraw-Hill : Irwin. 2001.

[16] Škerlič, S., Muha, R.: "The impact of various organisational measures on the logistics costs of companies in the automative industry," ICTTE : [proceedings]. Beograd: City Net Scientific Research Center, pp. 576-580, 2016.

[17] Themido, I., Arantes, A., Fernandes, C. and Guedes, A. P.: "Logistic Costs Case Study: An ABC Approach," Journal of the Operational Research Society 51(10), pp. 1148-1157, 2000.

[18] Van Damme, D.A. and van der Zon, F.L.A.: "Activity based costing and decision support," International Journal of Logistics Management 10(1), pp. 71-82, 1999.

[19] Varila, M., Seppanen, M. and Suomala, P.: "Detailed Cost Modelling: A Case Study in Warehouse Logistics," International journal of Physical Distribution \& Logistics Management 37(3), pp. 184-200, 2007.

[20] Waller, M. A. and Fawcett, S. E.: "The Total Cost Concept of Logistics: One of Many Fundamental Logistics Concepts Begging for Answers," Journal of Business Logistics 33(1), pp. $1-3,2012$.

[21] Wheatley, M. J.: "The real work of knowledge management," IHIRM Journal 5(2), pp. 29-33, 2001. 